\title{
3 Macroeconomics and monetary policy as autonomous domains of knowledge and power
}

\author{
Rational expectations, monetarism \\ and the Federal Reserve
}

Jan Sparsam and Hanno Pahl

\section{Introduction: economic knowledge on planet academia and in central banks}

In this chapter, ${ }^{1}$ we argue that although practical monetary policy is strongly influenced by academic macroeconomics, this does not imply that developments in both domains run in parallel. As has been shown in numerous sociological works on the fabrication and application of scientific knowledge, especially in the so-called laboratory studies, knowledge production is always situated in social contexts that have an impact on the respective forms of knowledge (Knorr Cetina, 1981). Knowledge production in academic macroeconomics is also structured by a rather different social context than monetary policy. The main area of application of macroeconomics is supposed to be central banks. The power structure as well as the practical needs in both domains differ significantly, resulting in distinct epistemic cultures. Therefore, we pose the questions of what attempts to influence monetary policy with macroeconomic knowledge would actually look like and how macroeconomic ideas are conceived by practitioners.

The relevance of the questions stems not least from recent criticisms of mainstream macroeconomics as articulated by heterodox economists, the media, but also by central bankers themselves: Many different commentators have explained the outbreak of the crisis in 2008 as well as the initial helplessness of central banks at least partially with deficits of current mainstream macroeconomics. In particular, they criticized the merely rudimentary role of financial markets in the standard models of new Keynesian economics - currently the leading school of macroeconomics and the new mainstream (Leijonhufvud, 2009; Borio, 2012).

Focusing on the Federal Reserve, we argue that this diagnosis is not wrong but simplistic. Even though decision making in the Fed has been influenced by mainstream macroeconomics all along, the knowledge culture of the Federal Open Market Committee (FOMC), the Fed's highest decision-making 
body, consists of more ingredients and actions than simply applying the actual standards of academic macroeconomics. ${ }^{2}$ The existing literature tends to downplay the frictions that go along with knowledge transitioning from academia to practice. This is especially true for mainstream accounts of macroeconomics (e.g. Woodford, 2009), but also for their critical counterparts from global political economy (e.g. Grabel, 2000). Both assume a much too straightforward impact - praised by mainstream economists (suggesting monetary policy has become better due to technical expertise offered by academic macroeconomics), criticized by critical political economists (monetary policy as captured by neoliberal academic schools, c.f. Sparsam \& Pahl, 2018). We argue that it is not predominantly the cognitive aspects of scientific knowledge and the criteria of success in academia that convince the practitioners to adopt macroeconomic concepts. In our opinion the context conditions of action in the respective domains are to a greater degree responsible for a - successful or failed - transition between them.

For our argument, we chose an episode that was historically crucial for the Fed and led to a paradigm change in monetary policy making. The transcripts of the meetings of the FOMC around 1978 and 1979 show that the politically critical situation for the Fed opened the deliberations of the FOMC for discursive interventions from its members that promoted specific macroeconomic ideas. The two cases we refer to are the absent impact of the so-called rational expectations revolution or, as it was labelled later, the rise of new classical macroeconomics and the adaption of monetarism in a practical way by the Fed under the chairmanship of Paul Volcker. Rational expectations macroeconomics emerged in the mid-1970s and led to a paradigm shift in academic macroeconomics within a few years (Mishkin, 1995; Hoover, 1992), with devastating effects for the credibility of the Keynesian mainstream. The influence of new classical macroeconomics on the Fed, however, remained rather modest for a long time. The reasons for this lag are quite opaque. In contrast, monetarism was allegedly adopted by the Fed with the debut of Volcker as chairman of the FOMC. The paradigm itself, however, did not revolutionize academic macroeconomics, and its main protagonist, Milton Friedman, is considered to be more of a political figure. But the history of macroeconomic thought is still struggling to answer the question in which way monetarism actually made an impact on the Fed's monetary policy.

Course of argument: The following section is divided into two subsections: We begin with sketching the broad support rational expectations macroeconomics received at one specific district of the Federal Reserve System, the Federal Reserve Bank of Minneapolis, as early as from the mid-1970s onwards (2.1). In the next subsection, we present empirical evidence to answer the question of why this support did not lead to a broader influence of new classical macroeconomics in the Fed, referring to the verbatim transcripts of the meetings of the FOMC. We discuss several examples from the late 1970s that shed some light on why the paradigm shift in academia did not have the same immediate impact on monetary policy (2.2). The following section deals with 
the so-called practical monetarism of Paul Volcker's chairmanship. We will show how impulses from academic macroeconomics were picked up by the Fed in a selective and pragmatic way (3). In the discussion, we argue that both academic macroeconomics and monetary policy making encounter fundamentally different problems and therefore need distinct solutions that require translations between both domains. Because of that, they have to be understood as autonomous domains of knowledge and power (4). Our contribution thus combines empirical findings with insights from the relevant literature, spanning the history of economic ideas and the history of central banking. ${ }^{3}$

\section{Why new classical macroeconomics has not taken the FOMC by storm}

\subsection{The Minneapolis Fed as a breeding ground for rational expectations macroeconomics in the $1970 \mathrm{~s}$}

The Federal Reserve System consists of twelve regional Federal Reserve Banks that are jointly responsible for planning and implementing monetary policy measures in their respective districts (Hafer, 2005). The huge degree of independence of the districts supports quite some diversity within the Federal Reserve System, especially with regard to their research activities and monetary policy positions. For example, the Federal Reserve Bank of St. Louis is considered to have been a stronghold of monetarism from the late 1960s onwards (see Hafer \& Wheelock, 2001). The same is true with respect to new classical macroeconomics for the Federal Reserve Bank of Minneapolis from the mid1970s onwards.

Monetarism, especially represented by Friedman, renewed the quantity theory of money. The main argument concerning monetary policy was that central banks have to directly control the money supply. Even though Friedman challenged the Keynesian mainstream (of the so-called old neoclassical synthesis), the impact of monetarist thought on the academic profession was rather limited (De Vroey, 2016, p. 85). Instead, its influence is mainly supposed to be a political one, promoting the market against the Keynesian statism (c.f. Accocella et al., 2016, p. 51). The success of monetarism, therefore, can mainly be seen in the establishment of politico-economical tenets like inflation fighting as the main goal of monetary policy (c.f. De Long, 2000). In contrast, new classical macroeconomics, opposing monetarism but being not a bit less market-oriented than Friedman, radically changed the research landscape of macroeconomics. Initiated by Robert E. Lucas, it set a new theoretical standard for econometric modelling. The so-called Lucas Critique conveys that Keynesian models are not able to reproduce economic actors adjusting their preferences when they encounter changes in policy. As a solution, Lucas proposed basing models on rational expectations, which means that economic actors are able to anticipate the effects of policy changes. In such models, economic actors behave as if they knew the parameters of the model (Snowdon \& Vane, 
2005, p. 228; De Vroey, 2016, p. 167). Lucas's solution provided a microfoundation for macroeconomic modelling and made it compatible with the microeconomic standard of general equilibrium theory (Sparsam et al., 2017). It also sparked the development towards building models as the main activity of macroeconomists and therefore providing new career opportunities (Colander, 1989, p. 33). ${ }^{4}$

At the Federal Reserve Bank of Minneapolis, during the directorships of Bruce MacLaury (1971-1977) and Mark H. Willes (1977-1980) the research focus shifted to the then brand-new theory of rational expectations, including an offensive proclamation of the market-affirmative and anti-Keynesian policy recommendations associated with this program. Regarding the propagation and popularization of this new theory and worldview, Willes stood out prominently. His predecessor remembers him in the following way:

Mark Willes, who came in as president after I left, was very intrigued with this line of reasoning [rational expectations] within the research department at the Federal Reserve in Minneapolis and made it more of an official policy line of this bank, a symbol, if you will, of this bank within the Federal Reserve System. So there became a voice for the rational expectation school coming out of Minneapolis. That grew out of work that was going on here while I was here, but I thought that it was a very interesting intellectual exercise, not a direct policy-related exercise while I was here.

(MacLaury, 1992, n.p.) ${ }^{5}$

Economist Neil Wallace (in Hoover \& Young, 2011, p. 27), one of the major contributors to new classical macroeconomics, who at that time belonged to the Bank's research staff, made similar comments:

When Mark Willes came to the Minneapolis Federal Reserve as president, he decided to publicize some of the research on rational expectations. In particular, Mark had the view that some of the policy-ineffectiveness stuff was something that deserved a hearing within the system. ${ }^{6}$

The Bank's new research agenda, which quickly led to relevant publications (such as Muench \& Wallace, 1974; Sargent \& Wallace, 1976), served as a multiplier effect that helped to spread Lucas's fundamental critique of the Keynesian paradigm in academic macroeconomics and stimulated research to make it more relevant for policy. Thomas Sargent (1995, p. 4), who also counts as a main protagonist of new classical macroeconomics today and worked in the research department of the Minneapolis Fed at the time, wrote about the influence of these interventions as follows:

Neil Wallace and I had already written several papers about rational expectations in 1969-1972, and had read drafts of Lucas's JET paper [1972] as well as two key papers by Lucas and Prescott [1971, 1974]. But we didn't 
understand what was going on until, upon reading Lucas's 'Econometric Policy Evaluation' in Spring of $1973,{ }^{7}$ we were stunned into terminating our long standing Minneapolis Fed research project to design, estimate and optimally control a Keynesian macroeconometric model.

Here, Sargent classifies Lucas's ideas as a crucial experience that radically redirected monetary policy research in Minneapolis. At the same time, the Federal Reserve Bank of Minneapolis Quarterly Review, launched in 1977, created a new series of publications at the intersection of academic discourse, monetary policy, and public relations, in which numerous articles proclaiming "radically different new directions" in theorizing as well as monetary policy (Lucas \& Sargent, 1979, p. 15) were subsequently published.

Willes himself used his position as president ${ }^{8}$ not only to readjust bankinternal research in Minneapolis but to attempt to popularize the new school of thought in the political field. In an interview he highlights this attempt as a main aspect of his presidential work:

I spent an enormous amount of time trying to help people be interested in public policy, help explain what public economic policy was, what kinds of effects it would have, what was possible, was what not possible. You take this last election discussion, and you could cry, because the general notion about what is possible is so far off the mark that people make really important decisions and then clamor for action, when often, if they get what they really ask for, they're going to be worse off, rather than better off.

(Willes, 1992, n.p.) ${ }^{9}$

These quotes show that Willes acted not only as a strong supporter of early new classical macroeconomics but also as a chaperone of its development. However, as will be subsequently shown, he was not able to establish the agenda of rational expectations at the power centre of the Fed, the FOMC, and we will examine some of the reasons of this failure.

\subsection{Failed interventions: Mark Willes's efforts at persuading the FOMC to adopt rational expectations macroeconomics}

The FOMC deliberates about and sets monetary policy and financial regulations. It comprises twelve voting members: seven members of the Board of Governors (BoG), nominated by the president of the USA and appointed by the Senate for a maximum term of fourteen years. Among these members are the respective chairs of the committee who, however, can only be appointed for consecutive four-year legislatures. The other five members of the FOMC are the presidents from the twelve Federal Reserve districts. The FOMC usually meets eight times a year to discuss and decide on the monetary policy stance of the Fed (see Meulendyke, 1998, pp. 121-138). 
As president of the Minneapolis Fed, Willes also participated in the FOMC, first as a non-voting member and since March 1978 as a voting member. During this time, he firmly positioned himself as radical proponent of tight monetary policy: "Mark Willes . . . wanted to use a sledgehammer rather than a scalpel in tightening credit" (Silber, 2012, p. 138). A statistical evaluation of the voting behaviour of the members of the FOMC ranks him "among the most tightness-oriented members" (Chappell et al., 2005, p. 44). At the same time, his voting behaviour showed an unusually high degree of dissent, bringing some turmoil to this rather consensus-oriented committee.$^{10}$ Reminiscing, Willes (1992, n.p.) made the following remarks about his time at the FOMC:

That was, of course, a time when there were some fairly sharply divergent views about how to manage things domestically. Even though I was president a relatively short period of time, I tended to get more than my share of attention, because I disagreed often with what the System was doing and how it was dealing with what I thought was a policy that was not going to deal with inflation as effectively as we ought to.

Willes did not only carry himself as a deviationist, ${ }^{11}$ but he has also offensively brought the ideas of rational expectations macroeconomics into the FOMC. Surprisingly, he has not succeeded in arousing any interest of the other members of the FOMC for the policy-relevant implications of this new variety of academic macroeconomics. In his extensive history of the Federal Reserve, Meltzer (2010, p. 1017) concludes for the period of the late 1970s to the early 1980s: "Academic literature at the time was dominated by models with rational expectations. .. President Mark Willes (Minneapolis) mentioned this work at times, but he did not get a response." It is instructive to take a closer look at some sequences of the verbatim transcripts of the meetings of the FOMC to investigate the main reasons for this failure. ${ }^{12}$

In the meetings of June and July 1978, Willes argued that the econometric models used by the Fed's scientific staff to inform the members of the FOMC fall short of properly including the expectations of economic actors (see June 20, 1978, p. 10; July 18, 1978, p. 16). In the September meeting of the same year, Willes refused to be regarded as an outsider concerning his preference for tight policy measures. He quoted a letter from the Fed to Congress that assures a long-run neutrality of monetary policy, criticizing that the Fed does not act the way it claims to do (September 8, 1978, p. 29). This did not lead to any kind of discussion, however. The first intervention by Willes that sparked a brief debate took place in the October meeting of 1978 . He again emphasized the importance of including rational expectations, referring to the work done at the Minneapolis Fed. Incorporating rational expectations, he argued, could substantially change the perceived impacts of various policy alternatives. Since the voting members based their decisions to set the funds rate at least partially on models and econometric analyses offered by the Fed's scientific staff, using alternative model specifications or alternative models might 


\section{Jan Sparsam and Hanno Pahl}

alter their perception of the economic situation. Staff member James L. Kichline admitted to Willes the need to improve the integration of expectations into their models, ${ }^{13}$ demonstrating that he is fully aware of the methodological problems coming along with this missing variable. But he was also cautious to align himself with the work done at the Minneapolis Fed by emphasizing that the outputs of the models might be different:

MR. KICHLINE. Yes. We have work going on now to try to incorporate in the various parts of the model a better expression of expectations than is now captured in the model. It's clearly a weak point of the model now. I guess my own judgment would be that perhaps we wouldn't get as strong a response as the results of your work in this area just looking at some of the early things we've done. But I think it's a quite valid comment that our model does not have in it as much of an "expectations" phenomenon throughout as [^your model] apparently. You're quite correct; I have no problem in saying that we have not progressed very far in putting that in the model.

(October 17, 1978, p. 13)

However, as the further discussion reveals, Willes's colleagues at the FOMC were not that much convinced of the importance of his objections. J. Charles Partee, member of the Board of Governors, asked Kichline if the model incorporating expectations the staff is working on is "based on some new theory" or "on historical experience" which Kichline affirmed (October 17, 1978, p. 13). With this statement he, on the one side, emphasized the methodological difference between Willes's and the staff's approaches. On the other side, he thereby proclaimed a hierarchy in the validity of different forms of knowledge for the FOMC's concerns, valuating pure theoretical insights as inferior to more datasaturated information. This claim that was also supported by chairman G. William Miller, who stressed that rational expectations models still were not able to adequately reproduce time series data:

MR. PARTEE [ ${ }^{\star}$ Board of Governors]. But I still think, Mark, the test of the pudding is in the replication of the past. Again, no matter what your theory is, it has to be a model that -

CHAIRMAN MILLER It's got to be proved throughout the cycle.

MR. PARTEE To show it works, and this one is based on the past.

(October 17, 1978, p. 13)

Although Willes tried to make clear that he was aiming at a qualitatively different "perception of policy impacts," (October 17, 1978, p. 13) the discussion quickly terminated because another member was called upon to comment on the economic situation.

This short episode is highly typical for Willes's failed interventions. The following meetings show similar sequences whenever Willes tried to bring his view to attention again. For instance, in the November meeting of the same 
year, he repeated his claim about expectations, but nobody even picked up on his points (November 21, 1978, p. 17). In the December meeting, a somewhat humorous but also polemical verbal exchange took place. Willes tried to distinguish the rational expectations research agenda from monetarism, while Partee regards both schools of thought as mere variations of the same paradigm:

MR. WILLES I would like first to make a commercial, Mr. Chairman, and disavow that I am a monetarist. We hold a balanced portfolio in Minneapolis. MR. PARTEE He's like an Episcopalian not being a Catholic.

MR. WILLES Someday when we have more time we will explain the substantive differences between the monetarist and what's even worse, I might say, and that's a rational expectations-ist. But that's another story.

(December 19, 1978, p. 28)

It is evident that Willes acted with the intention to single out the rational expectations school of thought as a new and independent stream of research in contrast to monetarism. His playful description of his intervention as advertising already shows that he was quite aware of the promotional character of his objections (and maybe their futility). His opponent played down his claim, by cracking a sarcastic joke, stealing Willes's thunder.

Later in the same meeting when the committee openly discussed the unavailability of different policy scenarios, Willes pointed out weaknesses in the models used by the Fed's staff again, arguing

that there is no way we can say on the basis of those exercises [ ${ }^{\star}$ simulations with the existing models] whether our proposed policy is consistent or inconsistent with the President's [ ${ }^{\star}$ economic] programs. My fear is that we are going to mislead ourselves into thinking that we can determine with more precision than we can exactly what the options are that we face.

(December 19, 1978, p. 58)

At this point, Willes seemed to be aware of the importance to not base his criticism only on general theoretical objections stemming from the rational expectations approach but to offer more data-saturated econometrical work to the committee and thereby a practical solution to the problems the FOMC identified in their mode of knowledge production. He continues:

We hope to have for the Committee, in a few months, some simulation views in the MTS [ ${ }^{\star}$ multivariate time series] model to indicate that there is really nothing we can say about the breakdown in nominal GNP between prices and real output, with any degree of confidence at all, based on the way that model is currently working. And that's not a criticism of that model any more than any other. It's just a fundamental difficulty we are having [in] how these things are being done.

(December 19, 1978, p. 58) 
Yet, it took Willes and his economic staff at Minneapolis much longer than expected to come up with econometric models (based on rational expectations) that would meet the needs of the FOMC. The first working models to adequately operationalize the Lucas Critique were the real business cycle models of the early 1980s (Kydland \& Prescott, 1982). But these models left no place for monetary policy whatsoever (beneath keeping inflation low) because they explained business cycles exclusively as results of technology shocks or other real factors (c.f. Hoover, 2007, p. 423). This characteristic rendered them very unattractive for the needs of the FOMC and the Federal Reserve System in general. Willes's objections in the FOMC that monetary policy may be completely futile as a means of affecting the economy that were based on the "policy ineffectiveness proposition" (Sargent \& Wallace, 1976) were also received as "very, very [specific]," (Partee, January 9, 1980, p. 59) but "very imprecise in terms of the numbers we come out with" (Schultz, vice chair Board of Governors, January 9, 1980, p. 59).

This interaction concerning rational expectations that took place between Willes and the FOMC almost like a ritual shows that the new paradigm that revolutionized macroeconomics did the very opposite in the FOMC. The transcripts reveal that in the committee it was conceived as a mere idiosyncrasy of one person. This also happened because the then crisis-ridden Fed referred to another academic paradigm to change its course: monetarism.

\section{Muddling through: practical monetarism at the Fed as a pragmatic choice}

Interestingly, in the beginning monetarism showed a similar fate in the Fed as rational expectations did. Before gaining influence in the FOMC, it was adopted in the Federal Reserve Bank of St. Louis. As Johnson shows (1998, p. 158), monetarism was explored by the staff at St. Louis concerning research and forecasts and had a significant impact on the respective president. However, similar to new classical macroeconomics in Minneapolis, the paradigm did not gain any influence in the FOMC's decisions in the early 1970s. According to Johnson (1998, p. 158), this was due to the pecking order that placed the staff of the FOMC above those of the districts. He also stresses that the presidents of St. Louis were ignored in the meetings.

But it was to turn out completely different: In August 1979 Paul Volcker became chairman of the FOMC. ${ }^{14}$ When he took office, the economic situation in the US was quite precarious because the economy was ridden by a severe "stagflation" - high inflation and low growth - for a few years by then, for which the Fed took a lot of public and political blame. This made it necessary for the FOMC to finally come up with a solution. With Volcker, the period of so-called practical monetarism began. Although Volcker's rigid antiinflation policy undoubtedly had greater common ground with Willes's policy preferences than with 1970s Keynesian economics, this rebuilding phase did 
not lead to a breakthrough for rational expectations theory at the Fed either. To quote Meltzer again,

Volcker did not take seriously the rational expectations claim that expectations would adjust quickly to his policy actions. . . . Both money growth and interest rates were highly variable, so it was difficult to hold firm expectations about future policy.

(Meltzer, 2010, p. 1063)

Volcker acted as a technocrat as well as a pragmatist: "At the Fed, Volcker wasn't worrying about models. He was exercising the Fed's monetary muscle, raising interest rates to double-digit levels to bring down inflation at the cost of a severe recession" (Wessel, 2009, p. 72f.).

To get as much public attention as possible, Volcker chose not only to tighten monetary policy, but also to announce a fundamental change in policy. He used the label "monetarism" (targeting the money supply), which Friedman as one of the most prominent public critics invoked against the Fed, as a powerful signifier for the policy shift: Instead of halting inflation just by raising interest rates aggressively, "Volcker decreed that the Fed would henceforth target the supply of money in the banking system - he would switch from manipulating the price of credit to policing the quantity of it" (Mallaby, 2016, p. 232). The choice to announce a shift to an allegedly monetarist strategy reflects what the FOMC thought it had as room for maneuver under the given political circumstances and the power structure in the committee itself, not a confession to the academic paradigm. As Lindsey et al. (2013, p. 536) declare,

The available record does not suggest that the FOMC was converted to monetarist ideology. The monetarist experiment of October 1979 was not really monetarist! Rather, the new techniques were conditionally adopted for pragmatic reasons - there was a good chance that they would succeed in restoring stability.

The decision to target the money supply in the October meeting was certainly not challenged by the Keynesians in the committee - they were just as helpless confronted with the phenomenon of stagflation, an occurrence that should have been impossible according to Keynesian thought.

This pragmatic turn to practical monetarism can be understood as a strategy to signal to public that the Fed was finally taking radical measures against soaring inflation (c.f. Mallaby, 2016, p. 232). Volcker represented to the outside that the new strategy was a long-term one (Axilrod, 2013, p. 79). On the inside, he urged the suspension of adverse inflation expectations to justify the policy shift (c.f. Hetzel, 2008, p. 150). He and the other members often used the term in the meetings of the FOMC. Practical monetarism was aimed at changing the "explosive inflationary psychology" (Balles, president Federal Reserve Bank 
of San Francisco, October 6, 1979, p. 16) that high inflation was a permanent feature of the economy: "We're going to have to break that psychology" (Teeters, Board of Governors, November 20, 1979, p. 24). It can be assumed that Volcker's emphasis on inflation expectations was less inspired by new classical macroeconomics than by an everyday philosophy of "market psychology" of economic actors, based on his experience at the trading desk at the New York Fed (see Volcker in Mehrling, 2007, p. 171). Therefore, practical monetarism did not follow the expectations of economic actors as new classical macroeconomics suggested but tried to shape the perception of what monetary policy is doing - with a highly uncertain outcome:

There has been a great deal of discussion about the money supply and the feeling that so much of this psychology is related to the fact that the money supply is out of control. That's the comment we hear all the time. The virtue of a new approach, if it has one, is that we are accepting - with all its risks and dangers - more of a focus on the money supply.

(Volcker, October 6, 1979, p. 15) ${ }^{15}$

Practical monetarism led to ambivalent results: On technical terms, the FOMC did not succeed in estimating the correct growth of the money supply. Therefore, it terminated the experiment in 1982 (c.f. Meltzer, 2010, p. 1229). However, on ideological terms, it was part of the broader shift to neoliberal politics that began in the late 1970s:

[T] here is no doubt that the global ideological climate changed significantly, the Fed being part of these developments: For instance, from August 1979 onwards, until December 2008, the FOMC made no longer any references to employment in its policy directives, focusing exclusively on price-level stability.

(Thornton, 2012, p. 117)

Ultimately, it was not a choice that followed academic recommendations and certainly not a technical precision coming along targeting the money supply that justified pursuing the overarching goal of monetarism - fighting inflation but the economic and discursive success of monetary policy under Volcker. ${ }^{16}$ It spread the impression that central banks can successfully intervene if they are independent and can fight inflation without instigating a recession (c.f. Goodfriend, 2007, p. 53). The new agenda, later supported by the conservative Reagan administration, “tipped America's balance of power much more in favor of those with dollars and against those with only votes" (Johnson, 1998, p. 147). Central banking - as it was framed from now on - should stay away from any attempts to support aggregate demand and a global management of the economy and should only care about keeping inflation low. Ironically, the success of the policy experiment that was called practical monetarism opened the doors for the successive paradigm of new classical macroeconomics 
that placed greater emphasis on the possible effects of monetary policy: new Keynesian economics.

\section{Discussion: monetary policy making and academic macroeconomics as autonomous domains of knowledge and power}

Our case studies show that the dissemination of academic macroeconomic ideas did not work in a straightforward way. What is convincing on planet academia does not have to be necessarily cogent for the practitioners in central banks. The failed intervention of Mark Willes reveals that even thorough local research and an aggressive propagation of the superiority of the paradigm did not nudge the committee into acknowledging its alleged benefits. The case reveals that new classical macroeconomics at that time was not prepared to fulfill the practical needs of the FOMC to work with models that suit and support the deliberation and decision-making process in the committee. In contrast, the implementation of practical monetarism demonstrates that the economic paradigm was used only in a pragmatic and selective manner by central bankers as part of their communication strategies as well as their operating procedures. It did not imply that central bankers necessarily stuck to the technical and ideological details of the respective paradigm.

The cases principally show that, even though academic macroeconomics and monetary policy have a strong connection, they have to be characterized as autonomous domains of knowledge and power. This is foremost due to the different problems the actors have to solve in both domains and the related distinct epistemic cultures. To put it bluntly: Macroeconomists have to construct parsimonious models as artificial worlds that can claim scientific validity regarding the rigid rules in the academic domain (see Morgan, 2012). Solutions for monetary policy coming from macroeconomists, therefore, can be quite monocausal and reductionist. A crucial point is that macroeconomists do not have to care about the practical implementation of monetary policy. In contrast, central bankers in the Fed have to make decisions about monetary policy that can be realized with the available instruments and legitimized to the public and Congress. Therefore, they draw on a plethora of different kinds of information and knowledge - the more, the better, not on models and their outcomes alone. Also, macroeconomic knowledge has to be translated into a practicable format the FOMC can use to make a decision confronting the complexity of the real-world economy. The transformations of knowledge in the FOMC proceed more incrementally than the scientific revolutions in macroeconomics (c.f. Sparsam \& Pahl, forthcoming).

The cases suggest that the organizational structure of the Fed permits it to focus on specific macroeconomic paradigms in the districts, but that the FOMC is hierarchically superior in its routine as well as its rationale for decision making. It holds the prerogative of interpretation of the economic situation and the adequacy of actions the Fed can take, and this is interestingly based 
in the tenet that macroeconomic paradigms must not override the autonomy of the deliberations in the FOMC (c.f. Blinder, 1998, p. 7). This autonomy is partially based on the role of the chair "as an agenda setter and as a consensus builder" (McGregor \& Young, 2014, p. 169). They have to channel the individual preferences and lead the meetings to a decision, with the relative freedom to divert the agenda of the meeting (and possibly taking the blame for a bad decision). But it is also established in a persistent organizational routine: The structure of the meetings of the FOMC has not substantially changed from the 1970 s to today. The meetings guarantee that every participant has the freedom to say whatever they think is important, but that a decision can be made even if preferences diverge substantially.

The autonomy of monetary policy even stays intact in times of a tighter relation between both domains. As is well known today, some of the theoretical standards as well as some of the policy recommendations from new classical macroeconomics were established since the 1990s. This influence occurred mainly through the mediation of new Keynesian economics, a paradigm that merged some ideas of new classical macroeconomics with features of the older Keynesian economics. Leading figures in the Fed, most notably Ben Bernanke and Janet Yellen, had some affinity for new Keynesian economics. Before becoming chairs, both already had significant influence on the Federal Reserve System: Bernanke as member of the Academic Advisory Panel of the New York Fed, and Yellen as member of the Board of Governors. Since 1995, the FOMC has increasingly discussed inflation targeting, the new Keynesian variant of a rule-based monetary policy that explicitly includes the formation of expectations by market actors in order to achieve monetary policy goals (cf. Gavin, 1996). Concerning models, new Keynesian discourse first enters the FOMC in 1996, when the FRB/US model was introduced. Although still in the tradition of older Keynesian models, it is already altered by new Keynesian specifications. But the aforementioned also applies in these cases: The extreme approach of the new classical economists has not fully removed Keynesian stabilization policies from the agenda of the central banks and presumably never will in an absolute fashion. To blame new Keynesian economics for the crisis denies the autonomy of the domains of knowledge and power that central banks are. Instead of searching for technical similarities between both domains, it would be more fruitful to see if their modes of operation are different maybe even opposed - variants of a pro-market belief system.

\section{Notes}

1 This chapter is based on the research project "From Modelling to Governance." In the project we analyzed the verbatim transcripts of the meetings of the Federal Open Market Committee (FOMC). The meetings of the FOMC are taped and transcribed afterwards. Since 1994 the transcripts are available to the public with a lag of five years (online: www.federalreserve.gov/monetarypolicy/fomc_historical_year.htm). The transcripts document the entire official proceedings of each of the FOMC's eight annual meetings and comprise around 60 to 120 pages. Our main focus was the problem of 
how the committee refers to macroeconomic ideas and econometric models for deliberating and deciding on monetary policy. Our approach is based on grounded theory analysis (Corbin \& Strauss, 2008). It was chosen because our analysis does not aim at the mere identification of economics terms or aspects of knowledge from academic macroeconomics but at the specific utilization of this knowledge in the FOMC, also considering ambivalences, translations, or the like. We explicitly do not offer a rational reconstruction of the FOMC's decision-making process (as most economic analyses do, e.g. Romer \& Romer, 2002; Chappell et al., 2005) but an interpretative reconstruction of knowledge production in the committee. The project was supported by the Bundesministerium für Bildung und Forschung [Federal Ministry of Education and Research] of Germany under Grant 01UF1503.

2 See the extensive case study in Sparsam and Pahl (forthcoming) for an in-depth microsociological analysis of the FOMC's knowledge culture.

3 Two qualifications have to be made: First, it is beyond the scope of this chapter to introduce the respective economic schools of thought that are of relevance for the development of macroeconomics in detail. One may refer here to the pertinent nontechnical literature (e.g. Snowdon \& Vane, 2005; De Vroey, 2016). Second, as we focus on knowledge utilization in central banks, we limit our discussion to aspects that can be shown empirically, avoiding too much guesswork. It is our aim to contest accounts that suggest causal and too straightforward linkages between academic economic ideas and practical monetary policy without looking at the level of concrete deliberations.

4 "Funding for rational expectations research rose rapidly in the late seventies as support for large-scale macromodels declined" (Newlon, 1989, p. 207).

5 See also Mishkin's (1995, p. 3) assessment: “The rational expectations paradigm was then wholeheartedly adopted by the research staff of the Federal Reserve Bank of Minneapolis, who then became the most active advocates for rational expectations within the Federal Reserve System."

6 Wallace, together with Thomas Sargent (1976), proposed that considering rational expectations in Lucas's sense, policy can have no systematic effect on the economy.

7 This paper was only published in 1976 but was made available earlier as a draft.

8 "Federal Reserve Bank presidents give many speeches and author policy-oriented articles that receive wide attention and sometimes advocate policy positions opposed by the Fed chairman and/or a majority of FOMC members" (Wheelock, 2000, p. 267).

9 See Willes (1979) as an example for promoting the policy assumptions of rational expectations, including a very polemical stance towards Keynesian economics.

10 Chappell et al. (2005, p. 82f.) offer the following details: "[H]e did vote at eleven meetings and cast dissenting votes six times. As we have noted, a dissent frequency of this magnitude is unusual."

11 Willes often played the role of the dissenter in the committee quite dramatically: "My wife made me promise that I would be more agreeable in the new year, so I would like to say that I agree with everything that has been said. I'd like to say it, but the fact is that I don't agree" (January 8, 1980).

12 The following discussion is limited to selected empirical evidence. It is beyond the scope of this chapter to present a full-fledged account of the style and procedure of FOMC deliberations. See the aforementioned paper by Sparsam and Pahl (forthcoming) for such an account. We are citing from the transcripts of the FOMC stating name, position first time the name occurs, date of the meeting, and page of the transcript. Remarks in square brackets are in the original; our own additions are denoted with [ $\star$ ].

13 Interpreting this passage requires keeping in mind that the staff usually replies approbatively to inquiries of the members of the FOMC.

14 In early 1979, under chairman Miller, the FOMC showed serious signs of disunity, ultimately leading to the chairman's dismissal (see Bailey \& Schonhardt-Bailey, 2008).

15 The necessary operations coming along with practical monetarism were very vague for the FOMC. The staff of the FOMC had to answer a lot of technical questions in the 
beginning (see especially the transcript of January 8 and 9, 1980). Quite uncommon, the meetings turned into events to acquire basic knowledge in technical terms.

16 After a peak in the rate of inflation in 1980, it steadily declined (see Goodfriend \& King, 2005, pp. 982-983).

\section{References}

Accocella, N., Di Bartolomeo, G., \& Hughes Hallet, A. (2016). Macroeconomic Paradigms and Economic Policy: From the Great Depression to the Great Recession. Cambridge: Cambridge University Press.

Axilrod, S. H. (2013). The Federal Reserve: What Everyone Needs to Know. Oxford: Oxford University Press.

Bailey, A., \& Schonhardt-Bailey, C. (2008). Does Deliberation Matter in FOMC Monetary Policymaking? The Volcker Revolution in 1979. In: Political Analysis, 16 (4), 404-427.

Blinder, A. S. (1998). Central Banking in Theory and Practice. Lionel Robbins Lectures. Cambridge, MA: MIT Press.

Borio, C. (2012). The Financial Cycle and Macroeconomics: What Have We Learnt? (BIS Working Papers, 395). www.bis.org/publ/work395.pdf.

Chappell, H. W., McGregor, R. R., \& Vermilyea, T. (2005). Committee Decisions on Monetary Policy. Evidence from Historical Records of the Federal Open Market Committee. Cambridge, MA: MIT Press.

Corbin, J., \& Strauss, A. (2008). Basics of Qualitative Research. Techniques and Procedures for Developing Grounded Theory. Thousand Oaks: Sage Publications.

De Long, B. (2000). The Triumph of Monetarism? In: Journal of Economic Perspectives, 14 (1), 83-94.

Gavin, W. T. (1996). The FOMC in 1995: A Step Closer to Inflation Targeting? In: Federal Reserve Bank of St. Louis Review, September-October. https://files.stlouisfed.org/files/ htdocs/publications/review/96/09/9609wg.pdf.

Goodfriend, M. (2007). How the World Achieved Consensus on Monetary Policy. In: Journal of Economic Perspectives, 21 (4), 47-68.

Goodfriend, M., \& King, R. G. (2005). The Incredible Volcker Disinflation. In: Journal of Monetary Economics, 52 (5), 981-1015.

Grabel, I. (2000). The Political Economy of 'Policy Credibility': The New-Classical Macroeconomics and the Remaking of Emerging Economies. In: Cambridge Journal of Economics, 24 (1), 1-19.

Hafer, R. W. (2005): The Federal Reserve System. An Encyclopedia. Westport, CT: Greenwood Press.

Hafer, R. W., \& Wheelock, D. C. (2001). The Rise and Fall of a Policy Rule: Monetarism at the St. Louis Fed, 1968-1986. In: Federal Reserve Bank of St. Louis Review, JanuaryFebruary, 1-24. https://research.stlouisfed.org/publications/review/01/0101rh.pdf.

Hetzel, R. L. (2008). The Monetary Policy of the Federal Reserve: A History. Studies in Macroeconomic History. Cambridge and New York: Cambridge University Press.

Hoover, K. D. (1992). The Rational Expectations Revolution: An Assessment. In: Cato Journal, 12 (1), 81-106.

Hoover, K. D. (2007). A History of Postwar Monetary Economics and Macroeconomics. In: W. J. Samuels, J. Biddle, \& J. B. Davis (Eds.): A companion to the History of Economic Thought. Malden, MA: Blackwell, 411-427.

Hoover, K. D., \& Young, W. (2011). Rational Expectations: Retrospect and Prospect. A Panel Discussion with Michael Lovell, Robert Lucas, Dale Mortensen, Robert Shiller, 
Neil Wallace. Moderated by Kevin Hoover and Warren Young. (CHOPE Working Paper, 2011-10). www.dklevine.com/archive/refs4786969000000000227.pdf.

Johnson, Peter A. (1998). The Government of Money: Monetarism in Germany and the United States. Ithaca and London: Cornell University Press.

Knorr Cetina, K. D. (1981). The Manufacture of Knowledge. An Essay on the Constructivist and Contextual Nature of Science. Oxford: Pergamon Press.

Kydland, F. E., \& Prescott, E. C. (1982). Time to Build and Aggregate Fluctuations. In: Econometrica, 50 (6), 1345-1370.

Leijonhufvud, A. (2009). Macroeconomics and the Crisis: A Personal Appraisal (ARC 2009 Opening Lecture, Crisis and Reform, Brussels). http://ec.europa.eu/economy_finance/ events/2009/20091015/0-leijonhufvud_en.pdf.

Lindsey, D. E., Orphanides, A., \& Rasche, R. H. (2013). The Reform of October 1979: How It Happened and Why. In: Federal Reserve Bank of St. Louis Review, NovemberDecember, 487-542.

Lucas, R. E., \& Sargent, T. J. (1979). After Keynesian Macroeconomics. In: Federal Reserve Bank of Minneapolis Quarterly Review, 3 (2), 1-16.

MacLaury, B. K. (1992). Interview with Bruce K. MacLaury. Interview conducted by James E. Fogerty. www.minneapolisfed.org/about/more-about-the-fed/history-of-the-fed/ interview-with-bruce-k-maclaury.

Mallaby, S. (2016). The Man Who Knew. The Life and Times of Alan Greenspan. London: Bloomsbury Publishing.

McGregor, R. R., \& Young, W. (2014). Federal Reserve Bank Presidents as Public Intellectuals. In: History of Political Economy, 45 (Supplement 1), 166-190.

Mehrling, P. (2007). An Interview with Paul A. Volcker. In: P. A. Samuelson \& W. A. Barnett (Eds.): Inside the Economists Mind: The History of Modern Economic Thought, as Explained by Those Who Produced It. Malden, MA: Blackwell, 165-191.

Meltzer, A. H. (2010). A History of the Federal Reserve. Volume 2, Book 2, 1970-1986. Chicago: University of Chicago Press.

Meulendyke, A.-M. (1998). U.S. Monetary Policy and Financial Markets. New York: Federal Reserve Bank of New York.

Mishkin, F. S. (1995). The Rational Expectations Revolution: A Review Article of: Preston J. Miller, Ed.: The Rational Expectations Revolution, Readings from the Front Line (NBER Working Paper Series, 5043). www.nber.org/papers/w5043.pdf.

Morgan, M. S. (2012). The World in the Model. How Economists Work and Think. Cambridge: Cambridge University Press.

Muench, T., \& Wallace, N. (1974). On Stabilization Policy: Goals and Models. In: The American Economic Review, 64 (2), 330-337.

Newlon, D. H. (1989). The Role of the NSF in the Spread of Economic Ideas. In: D. Colander \& A. Coats (Eds.): The Spread of Economic Ideas. Cambridge: Cambridge University Press, 195-228.

Romer, C. D., \& Romer, D. H. (2002). The Evolution of Economic Understanding and Postwar Stabilization Policy. In: Federal Reserve Bank of Kansas (Ed.): Proceedings Economic Policy Symposium - Jackson Hole. Kansas: Federal Reserve Bank of Kansas, $11-78$.

Sargent, T. J. (1995). Adaptation of Macro Theory to Rational Expectations (Manuscript). http:// minneapolisfed.contentdm.oclc.org/cdm/ref/collection/p16030coll1/id/32.

Sargent, T. J., \& Wallace, N. (1976). Rational Expectations and the Theory of Economic Policy. In: Journal of Monetary Economics, 2 (2), 169-183.

Silber, W. L. (2012). Volcker. The Triumph of Persistence. New York: Bloomsbury Press. 


\section{Jan Sparsam and Hanno Pahl}

Snowdon, B., \& Vane, H. R. (2005). Modern Macroeconomics. Its Origins, Development and Current State. Cheltenham, UK and Northampton, MA: E. Elgar.

Sparsam, J., Nies, S., \& Pahl, H. (2017). Der Aufstieg der New Classical Macroeconomics: Zum (un-)gleich-zeitigen Wandel von Steuerungsparadigmen in der Makroökonomik und in Zentralbanken. In: S. Lessenich (Ed.): Geschlossene Gesellschaften. Verhandlungen des 38. Kongresses der Deutschen Gesellschaft für Soziologie in Bamberg 2016. http://publika tionen.soziologie.de/index.php/kongressband_2016.

Sparsam, J., \& Pahl, H. (2018). Soziologie der Zentralbanken. Makroökonomisches Wissen und Geldpolitik. In: C. Trampusch \& J. Beyer (Eds.): Finanzmarkt, Demokratie und Gesellschaft. 58. Sonderheft der Kölner Zeitschrift für Soziologie und Sozialpsychologie. Wiesbaden: Springer VS, 343-366.

Sparsam, J., \& Pahl, H. (forthcoming). Central Banking as Scenario Building: The Utilization of Macroeconomic Knowledge in the Federal Open Market Committee (Manuscript, under review).

Thornton, D. L. (2012). The Dual Mandate: Has the Fed Changed Its Objective? In: Federal Reserve Bank of St. Louis Review, 94 (2), 117-133.

Vroey, M. de (2016). A History of Macroeconomics from Keynes to Lucas and Beyond. New York: Cambridge University Press.

Wessel, D. (2009). In Fed We Trust. Ben Bernanke's War on the Great Panic. New York: Crown Business.

Wheelock, D. C. (2000). National Monetary Policy by Regional Design: The Evolving Role of the Federal Reserve Banks in Federal Reserve System Policy. In: J. von Hagen \& C. J. Waller (Eds.): Regional Aspects of Monetary Policy in Europe. New York: Springer Science and Business Media, 241-274.

Willes, M. H. (1979). Rational Expectations as a Counterrevolution. Manuscript. https://fraser. stlouisfed.org/title/?id=1115\#!1480.

Willes, M. H. (1992). Interview with Mark $H$ Willes, President of the Federal Reserve Bank of Minneapolis, 1977-1980. Interview conducted by James E. Fogerty, Minnesota Historical Society. December 8, 1992. www.minneapolisfed.org/about/more-about-the-fed/ history-of-the-fed/interview-with-mark-h-willes.

Woodford, M. (2009). Convergence in Macroeconomics: Elements of the New Synthesis. In: American Economic Journal, 1 (1), 267-279. 